\section{Let's re-examine these MTX points once again}

Duran et al may have missed my point. If so, this is my fault in that I must not have made it clearly enough. I detected a clear implication of industry bias in the thrust and premise of their findings. To support this position, they extrapolate from studies which purport to illustrate the wisdom of the implications of their review. They correctly point out that one of the references I quoted in the editorial ${ }^{1}$ on methotrexate (MTX) folate singlenucleotide polymorphisms (SNPs) leading to different outcomes employed higher doses of MTX and there was little difference in reported toxicity between 15 and $25 \mathrm{mg}$ of the drug when administered parenterally. ${ }^{2}$

I am sure that Duran et al would agree that one can support, or undermine, virtually any premise by selectively focusing on elements of the published literature which buttress and resonate with a particular position. The publication by Schiff et $a l^{3}$ which they have used to support their premise that SQ MTX at higher doses is associated with 'no increase in toxicity', was sponsored by a company that manufactures a parenteral form of MTX for the market.

It thus seems that they are selectively quoting a (very good) pharmaceutical-sponsored investigation when it supports their position, but imply bias in design elements in the other pharmaceutical sponsored research that they have analysed in their publication. $^{4}$

Perhaps Duran et $a l^{5}$ had not recognised the clear irony in their letter by focusing on ref. 4 to support their bias?

Yes, there are studies, some of which I have co-authored, showing that parenteral MTX is associated with improved bioavailability and therefore superior efficacy, but there has never been a study showing that patients would uniformly and predominantly benefit from an increase of 20 to $25 \mathrm{mg}$ of parenterally administered weekly MTX without experiencing more toxicity, over efficacy. This is not a technicality. It is a fact. And, yes, it is possible to point to studies that imply that their particular position does indeed represent what is likely to be true. The key words here are 'imply', and 'likely'.

I think that I would have been happier with the publication by Duran et al if they had framed their findings more carefully. That is, it is indeed possible that an ideal dose of MTX, when administered parenterally, was not used in the publications they quote, but before we take an additional step of assigning a negative bias to a large number of previously published trials, we need to tap into the better parts of our nature by assigning a judicial perspective that could have been improved upon. Duran et al have performed a service by focusing on the dose and route of administration issues of MTX in the literature they quote. However, the authors display a 'guilty until proven innocent' mentality in their approach to the analysis of these trials. There is a degree of sanctimony here, which is both unnecessary and distasteful.

\section{J M Kremer}

Correspondence to Professor J M Kremer, The Center for Rheumatology, Albany, 1367 Washington Avenue, Albany, NY 12206, USA; jkremer@joint-docs.com

\section{Competing interests None declared.}

Provenance and peer review Commissioned; internally peer reviewed.

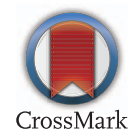

To cite Kremer JM. Ann Rheum Dis 2016;75:e54.

Received 9 May 2016

Accepted 14 May 2016

Published Online First 10 June 2016

\section{Linked}

http://dx.doi.org/10.1136/annrheumdis-2016-209791

Ann Rheum Dis 2016;75:e54. doi:10.1136/annrheumdis-2016-209834

\section{REFERENCES}

1 Kremer JM. Bias? Not so fast. Ann Rheum Dis 2016; Published Online First 20 Apr 2016. doi:10.1136/annrheumdis-2016-209505

2 Wessels JA de Vries-Bouwstra JK, Heijmans BT, et al. Efficacy and toxicity of methotrexate in early rheumatoid arthritis are associated with single-nucleotide polymorphisms in genes coding for folate pathway enzymes. Arthritis Rheum 2006; $54: 1087-95$

3 Schiff MH, Jaffe JS, Freundlich B. Head-to-head, randomized, crossover study of oral versus subcutaneous methotrexate in patients with rheumatoid arthritis: drug-exposure limitations of oral methotrexate at doses $>15 \mathrm{mg}$ May be overcome with subcutaneous administration. Ann Rheum Dis 2014;73: 1549-51.

4 Duran J, Bockorny M, Dalal D, et al. Methotrexate dosage as a source of bias in biological trials in rheumatoid arthritis: a systematic review. Ann Rheum Dis 2016; Published Online First 18 Apr 2016. doi:10.1136/annrheumdis-2016-209383

5 Duran J, Felson DT. Why methotrexate suboptimal dosing is a potential source of bias in biologic drugs clinical trials. Ann Rheum Dis 2016;75:e53. 